ORIGINAL ARTICLE

\title{
Ecological studies of mayflies (Insecta, Ephemeroptera): Can sampling effort be reduced without losing essential taxonomic and ecological information?
}

\author{
Yulie SHIMANO ${ }^{1 *}$, Mylena CARDOSO ${ }^{2}$, Leandro JUEN² \\ 1 Universidade Federal do Pará/Museu Paraense Emílio Goeldi, Programa de Pós-graduação em Zoologia, Rua Augusto Correia 1, Bairro Guamá, CEP 66075-110, \\ Belém, PA, Brasil \\ 2 Universidade Federal do Pará, Instituto de Ciências Biológicas, Laboratório de Ecologia e Conservação, Rua Augusto Correia 1, Bairro Guamá, CEP 66075-110, Belém, \\ PA, Brazil \\ * Corresponding author: shimano.yulie@gmail.com
}

\begin{abstract}
The present study evaluated the potential for the reduction of sampling effort in studies of ephemeropteran nymphs in Brazilian Amazon streams, Pará State, Brazil, without the loss of ecological information (species composition, abundance, and richness), and the congruence of different levels of taxonomic resolution (morphospecies, genus, family and functional group). Test groups of 15, 10 and five subsamples were selected from the 20 subsamples collected per stream (40 streams sampled), and were compared in terms of their species richness and abundance (ANOVA), and composition (Procrustes). Taxonomic resolution was also analyzed in Procrustes. Species abundance $\left(\mathrm{F}_{(3,156)}=25.426 ; \mathrm{p}<0.001\right)$ and richness $\left(\mathrm{F}_{(3,156)}=13.866, \mathrm{p}<\right.$ 0.001 ) varied significantly among sample groups, while the results of the $15-S$ group were statistically similar, in both cases, to those of the 20-S group. A similar pattern was found for species composition. The genus-level taxonomic resolution produced results $99 \%$ similar to those found for the species-level data. The results indicate that the reduction in sampling effort from 20 to 15 subsamples per site and a genus-level taxonomic resolution would not affect the reliability of analyses significantly. A reduction of five samples per site would result in a decrease of effort in the field and the amount of material to be processed, reducing laboratory time. In addition to a reduction in the time and resources needed to identify specimens, the adoption of a genus-level taxonomic resolution could help minimize errors of under- or over-estimation in the processing of the results.
\end{abstract}

KEYWORDS: congruence, environmental monitoring, functional feeding group, taxonomic resolution

\section{Estudos ecológicos com Ephemeroptera (Insecta): 0 esforço amostral pode ser reduzido sem perder informações ecológicas e taxonômicas?}

\section{RESUMO}

O presente estudo avalia o potencial para redução do esforço amostral em estudos com ninfas de Ephemeroptera em igarapés amazônicos, no estado do Pará, Brasil, sem perder informaçóes ecológicas (composição de espécies, abundância e riqueza), além de verificar se existe congruência entre diferentes níveis de resolução taxonômica (morfoespécie, gênero, família e grupo funcional). Grupos reduzidos de 15, 10 e cinco subamostras de um controle de 20 amostras de cada um dos 40 igarapés amostrados, foram comparados quanto a riqueza de táxons e abundância (ANOVA) e composição (Procrustes). A resolução taxonômica também foi avaliada através do Procrustes. A abundância $\left(\mathrm{F}_{(3,156)}=25.426 ; \mathrm{p}<0.001\right)$ e riqueza $\left(\mathrm{F}_{(3,156)}=13.866, \mathrm{p}\right.$ $<0.001$ ) variaram significativamente entre os grupos de amostras, porém, os resultados tanto de riqueza quanto de abundância dos grupos 15-S foram estatisticamente similares ao de 20-S. O mesmo padrão foi encontrado para riqueza de espécies. A resolução taxonômica a nível de gênero obteve $99 \%$ de congruência com a de morfoespécie. Esses resultados indicam que a diminuição de 20 subamostras para 15, e a redução da identificação de morfoespécie para gênero não afetaria a significância das análises. A redução de cinco amostras por local de coleta poderia resultar em uma diminuição do esforço em campo e do material para ser processado em laboratório, reduzindo o tempo de triagem e identificaçáo. Ainda, para reduzir tempo e recursos financeiros gastos para coleta e identificação dos organismos, a identificação apenas a nível genérico poderia minimizar erros de sub ou super estimativa no processamento dos resultados.

PALAVRAS-CHAVE: congruência, monitoramento ecológico, grupos funcionais alimentares, resolução taxonômica 


\section{INTRODUCTION}

Aquatic macroinvertebrates play a fundamental role in the transformation of organic material, energy flow, and nutrient cycling (Dodds 2002). Most species depend on specific environmental conditions and are highly sensitive to modifications of their environment. Given this, these insects are extremely effective as bio-indicators of environmental quality, reflecting not only specific local conditions, but also more general pollution levels (Martins et al. 2014). Aquatic macroinvertebrates are thus used for the biomonitoring of aquatic ecosystems in a number of different countries (Roque et al. 2014; Ghani et al. 2016).

Many recent studies in aquatic ecology have investigated broad themes such as changes in the composition of assemblages and functional groups along a longitudinal gradient (from the headwaters to the mouth of a watercourse), while others have evaluated the distribution patterns of macroinvertebrates (Brasil et al. 2014), and the organization of communities and their biological features at different scales (Callisto et al. 2012). While an increasing number of macroinvertebrate studies are being published, many lacunae persist in the understanding of the ecological characteristics of these organisms, and these require further attention. Basic questions have yet to be studied, such as the efficiency of different data collection procedures and the adequacy of the different taxonomic resolutions applied. Indeed, according to Phillips et al. (2003), sampling efficiency and the taxonomic resolution are examples of limiting factors for biodiversity studies in the tropics.

Aquatic habitats can vary in characteristics such as current velocity, substrate type (from sandy to rocky), water transparency, and the presence of organic matter (live or dead). Given such extensive diversity in environmental conditions, a number of different procedures have been used for the sampling of benthonic macroinvertebrates (e.g. surber, dredges, sieves, others). Moreover, strategies of specimen collection and sampling design may differ in terms of the number of samples, treatments, and the size of the study area sampled (e.g. Callisto et al. 2005).

Additionally, great variation exists in the taxonomic level used in ecological studies. Most studies of macroinvertebrates have been based on identification of specimens to the family level (e.g. Baptista et al. 2007), while a few more detailed studies have used genus-level classification (e.g. Tonello et al. 2014) and functional groups (e.g. Brasil et al. 2014). The identification of species is important because different species of the same genus may not always be comparable in their ecophysiological requirements or environmental tolerance (Merritt et al. 2007). However, species-level identification of specimens requires time and taxonomic expertise. Given this, identification of specimens to higher taxonomic levels has a number of practical advantages, such as a reduction in the effort and costs of collecting and identifying organisms, a decrease in the time and effort needed for training in identification, and an overall reduction in the risk of identification errors (Khan 2006). There is considerable debate on the optimal experimental design, and sampling, data processing, and analytical approaches for ecological research (Jones 2008), and one of the most contentious issues is the selection of the most appropriate taxonomic level that can guarantee the most reliable evaluation of the ecological signal being investigated.

Accordingly, to test the hypothesis that sampling and taxonomic effort can be reduced without compromising the reliability of results, the present study focused on the order Ephemeroptera, which are difficult to identify to the species level. While the adults can be identified more reliably, the larvae are typically used for biomonitoring (Dodds 2002; Barber-James et al. 2008), given that they tend to include representatives of all functional ecological categories (Salles and Da-Silva 2015), which reinforces their utility in understanding of ecosystem services. The order Ephemeroptera comprises a small group of insects that mostly have an aquatic nymphal stage (Barber-James et al., 2008), and a brief adult life during which dispersal, copulation, and oviposition occur (Domínguez et al. 2006). The emergence of ephemeropteran nymphs is responsible for the transfer of large amounts of phosphates and nitrates from the aquatic ecosystem to terrestrial environments (Edmunds et al. 1976). As these insects are highly sensitive to environmental change, and show a wide range of responses to such events, they are one of the groups most commonly used in water quality biomonitoring programs (Buss and Salles 2007; Domínguez et al. 2006).

In this way, our objectives were: (a) to investigate if the reduction in the number of subsamples influences significantly richness, abundance and composition of species/ morphospecies of Ephemeroptera (sample effort) and (b) to analyze the degree of congruence among the different taxonomic resolutions (family, genus, species/morphospecies or functional group). This permitted the assessment of the potential for the reduction of sampling effort and the taxonomic resolution without any significant loss of ecological information. We believe that, as ephemeropterans, like other macroinvertebrates used for biomonitoring, are highly sensitive to environmental alterations and are highly dependent on the composition and structure of micro- and meso-habitats (Souza et al. 2011; Chakona et al. 2008), ecological questions can be resolved adequately with a smaller number of subsamples and taxonomic identification at genus level.

\section{MATERIALS AND METHODS}

Data were collected in forested areas of the municipality of Paragominas in northeastern Pará state, Brazil. The local 
vegetation is classified as lowland terra firme rainforest, with smaller areas of dense alluvial rainforest (Hirai et al. 2008). The area has high rainfall (mean annual precipitation of 1766 $\mathrm{mm}$ ), a mean annual temperature of $27.2^{\circ} \mathrm{C}$, and $81 \%$ mean relative humidity (Watrin and Rocha 1992). Paragominas is drained by the basins of the Capim and Gurupi rivers, which are formed by a dense network of streams, including the Ananavira, Paraquequara, Candiru-Açu, Potiritá, Piriá, Uraim and Surubiju (Leal 2000).

A total of 40 streams were sampled, with a channel width of up to $5.5 \mathrm{~m}$ (Figure 1). Measurement of environmental variables in each stream was based on the protocol of Peck $e t$ al. (2006). A stretch of 150 meters of each stream was marked out and divided into 10 sections of 15 meters, which were then subdivided into three segments of five meters, resulting in 30 segments per stream (for details, see Juen et al. 2016). Only the first two segments of each section were sampled, with the third being used only to gain access to the other segments, thus avoiding the disturbance of the experimental segments in which data were collected (Figure 2A), with a total of 20 segments being sampled per stream. The mean sampling time per stream was one hour, not including sorting substrate. The sampling design adopted was developed to integrate the environmental analysis protocol of the Environmental Monitoring Program of the American Agency for Environmental Protection (Kaufmann et al. 1999), with

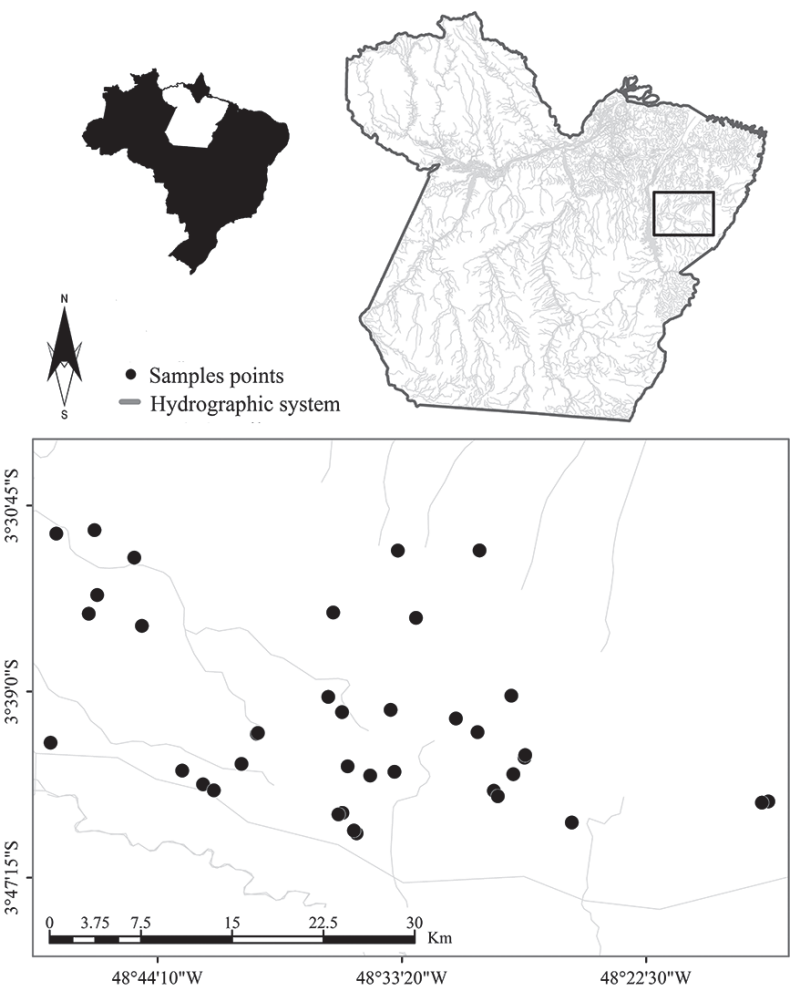

Figure 1. Sampling points for the collection of ephemeropteran nymphs in Paragominas, Pará, Brazil.

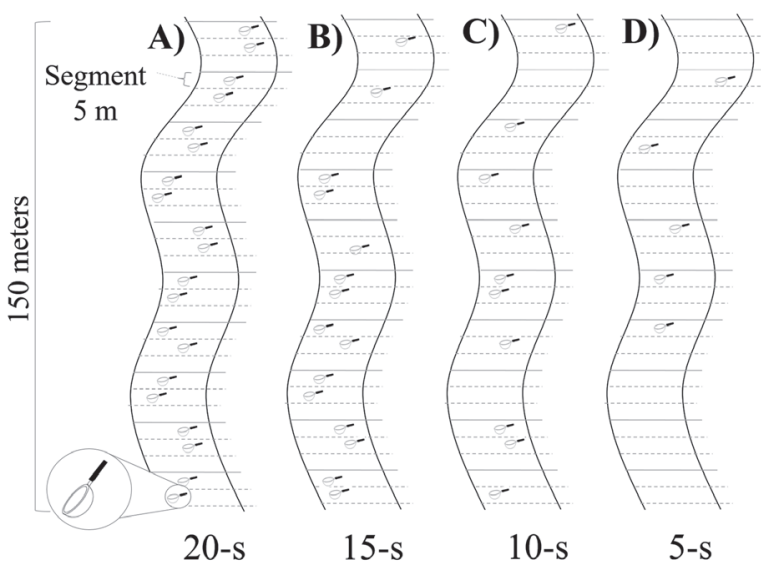

Figure 2. Schematic diagram showing (A) the collection of substrate samples; and the progressive reduction of sampling effort to include (B) 15 subsamples, (C) 10 subsamples or (D) 5 subsamples. In B, C and D, the subsamples were selected randomly in the R program, and the subsamples shown in the diagram are merely representative of the selection process.

the objective of adjusting the agency's environmental protocol (Peck et al. 2009) for-sampling living organisms, providing the potential for broader generalizations and comparisons with sampling procedures adopted in other countries.

Substrates present in each segment were sampled with a dipnet $(0.05 \mathrm{~mm}$ mesh), with a random portion of the substrate being sampled twice in each segment. Each subsample is composed of the substrate collected (two different samples) in each segment, with a total of 20 subsamples being collected per stream.

Substrate samples were processed in the field in white trays using entomological tweezers. Collected specimens were fixed in $85 \%$ alcohol. Functional groups were categorized based on the reviews of Shimano et al. (2012) and Brasil et al. (2014). Genus-level identification of specimens was conducted in the laboratory using the identification keys of Domínguez et al. (2006), with species being identified based on the available literature. When species-level identification was not possible, the specimens were allocated to morphospecies based on their morphological traits. In some groups (e.g., Miroculis, Campylocia and Farrodes), however, the immature insects are so similar to each other that it is impossible even to identify morphospecies consistently, and in these cases, we considered only the genera in the analyses. The identifications of generic and species/morphospecies levels were confirmed by Ephemeroptera specialist Dr. Frederico Falcão Salles of the Federal University of Espírito Santo. Following identification, the specimens were deposited in the entomological collection of the Ecology and Conservation Laboratory (LABECO) of the Federal University of Pará, Brazil.

All specimen collection was conducted during the dry season (July-November) in 2012 and 2013, in order to (i) reduce the possible effects of seasonal variation on results, (ii) 
because previous studies have shown that the highest species diversity is found during the period of lowest precipitation (Baptista et al. 2001), and (iii) because the shallower depth of the water column during this period is reflected in a greater availability of substrates to sample, and a greater density of individuals, so increasing capture probability of the greatest variety of species. The focus on a single seasonal period also reduces sampling "noise" in the analyses (Heino 2014).

To test the questions raised, sampling effort was manipulated through the selection of subsets of the subsamples collected from each stream. The 20 subsamples collected per stream were considered to be the control data set. We used the Subsampling.table application of the R program ( $R$ Development Core Team 2017) to choose the other three groups randomly (matrices), with 15 (15-S), ten (10-S) and five (5-S) subsamples per stream. The four matrices (one control, three test) were obtained for each stream, resulting in four groups of 40 streams.

In order to randomize the new three matrices with 15 , 10 and five subsamples, we used a table with 800 lines derived from the 20 subsamples collected from each of the 40 streams. From this table, the first test matrix (15-S) was derived from a random selection of 15 subsamples from the 20 available for each of the 40 streams. For the second test matrix (10-S), 10 subsamples were selected randomly from those available from each of the 40 streams, and in the third matrix (5-S), five subsamples were selected to represent each stream. Mean species richness and abundance were calculated for each stream, based on the data in each test matrix. Such randomization removes any potential bias in the selection of subsamples, and provides a simulation of a smaller number of samples obtained from the 150-m stretch of each stream. We tested these datasets (20-S, 15-S, 10-S and 5-S) for differences in species abundance, richness, and composition. This permitted testing of sampling effort and identification of taxa, and the principal question investigated was the potential for a reduction in the number of subsamples - permitting a reduction in the investment of time and financial resources while obtaining adequate results as effective as those produced with a larger sample.

The abundance and richness of species/morphospecies were compared among treatments (20-S, 15-S, 10-S and 5-S) using Analysis of Variance (ANOVA), following confirmation of the assumptions of homogeneity of variance and homoscedasticity (Zar 2010). Abundance data were $\log$-transformed $(\log 10[x+1])$ to reduce the effects of heteroscedasticity. When ANOVA results were significant, Tukey's a posteriori test was applied to identify differences between pairs of treatments.

To verify congruence in species composition among groups (20-S, 15-S, 10-S and 5-S) and among the different levels of taxonomic resolution (species, genus, family, and functional group), data from all composition matrices were summarized in a Principal Coordinates Analysis (PCoA), using the abundance of the specimens sampled. Abundance data were $\log$-transformed $(\log 10[\mathrm{x}+1])$ to minimize the effects of extreme outliers, and the Bray-Curtis dissimilarity index was applied. Once sampling and taxonomic resolution data were ranked, the degree of agreement among matrices was evaluated using a Procrustean routine (Jackson 1995). Procrustes Analysis is an overlap approach that compares a pair of ordinations using a rotational-fit algorithm to find the best adjustment in the corresponding ordinated observations. This analysis was based on the scores of the first two axes of each ordination (PCoA), given that these axes contain the majority of variability from the original data. Procrustes calculates the $\mathrm{m}^{2}$ statistic, which measures the degree of disparity in ordination patterns generated independently by the two sets of data (Legendre and Legendre 1998). All analyses were run in R software (R Development Core Team 2017), using the labdsv, mgcv and vegan packages.

\section{RESULTS}

Overall, 2701 ephemeropteran nymphs were collected, representing 26 species/morphospecies distributed in 20 genera and seven families (Table 1). Miroculis, Campylocia and Farrodes were the most abundant genera. Ulmeritoides flavopedes (Spieth, 1943) $(\mathrm{n}=90)$, Zelusia sp. $1(\mathrm{n}=62)$ and Hydrosmilodon aff. gilliasae Thomas and Péru, $2004(\mathrm{n}=27)$ were the most abundant species, and Callibaetis sp. $(\mathrm{n}=2)$, Microphlebia surinamenses Savage and Peters, $1983(\mathrm{n}=1)$ and Cloeodes sp. $1(\mathrm{n}=1)$ were the least abundant.

A significant difference $\left(\mathrm{F}_{(3,156)}=25.426 ; \mathrm{p}<0.001\right)$ was found in individual abundance when comparing sample groups (20-S, 15-S, 10-S and 5-S), although the posthoc analysis (Figure $3 \mathrm{~A}$ ) revealed that the abundance was statistically similar between $20-S$ and $15-S$ (Tukey's $p=0.215$ ) and $15-S$ and 10-S (Tukey's $\mathrm{p}=0.060$ ), while significant differences (Tukey's $\mathrm{p}<0.001$ ) were found in all other cases. On average, 19 specimens were lost when the sampling was reduced from 20-S to 15-S. A further 17 were lost between $15-S$ and $10-S$, and 16 between $10-S$ and 5-S. Overall, reducing the sample from 20-S to 5-S, resulted in the loss of 52 specimens per stream.

Species richness also varied significantly among sample groups $\left(\mathrm{F}_{(3,156)=} 13.866, \mathrm{p}<0.001\right)$, with the same pattern being observed for individual abundance (Figure 3B), i.e., no significant difference was found between 20-S and 15-S (Tukey's $\mathrm{p}=0.466$ ) and 15-S and 10-S (Tukey's $\mathrm{p}=0.341$ ), while Tukey's $\mathrm{p}$ was less than 0.001 for all other comparisons. On average, one species was lost per stream when sampling was reduced from 20-S and 15-S, one was lost between 15-S and $10-S$, and two species were lost per stream when sampling was reduced from $10-S$ to $5-S$. 
When analyzing the groups by species composition, all relationships were significantly congruent (Table 2 ). The highest level of congruence was found between 20-S and $15-S(95.3 \%), 20-S$ and $10-S(82.65 \%)$, and $15-S$ and $10-\mathrm{S}(80.0 \%)$. While the comparison between the smallest (5-S) and largest subsamples (20-S) was also significant, the explanatory correlation was only $59.8 \%$, with a $64.19 \%$ loss of information.

The different taxonomic resolutions were also significantly congruent (Table 3). There was a very high degree of agreement (99\%) between resolution at the species/morphospecies level and that of genus, with a loss of information of less than $1 \%$. High levels of correlation $\left(r^{2}>0.80\right)$ were also found between genus and family, and genus and functional groups, while the lowest correlation was recorded between family and functional groups $\left(r^{2}=0.709\right)$.
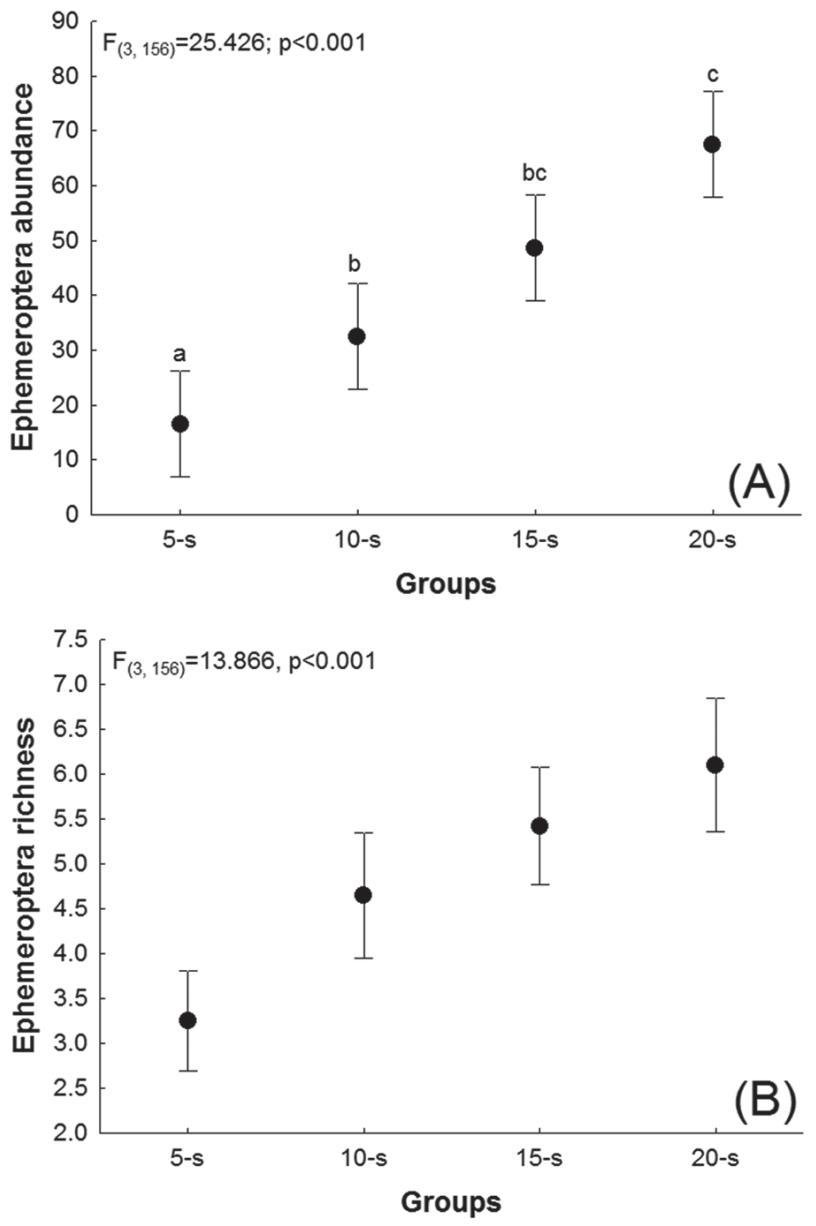

Figure 3. Analysis of Variance comparing (A) the abundance and (B) species richness of the ephemeropteran nymphs collected in 40 well-conserved Amazonian streams in groups of five (5-S), 10 (10-S), 15 (15-S), and 20 (20-S) subsamples per stream. The points correspond to the mean values and the bars to their standard deviations.
Table 1. Species and morphospecies of ephemeropteran nymphs sampled between September - December of 2012 and 2013 in 40 streams in Paragominas, Pará, Brazil. Functional feeding group classification was based on Shimano et al. (2012) and Brasil et al. (2014).

\begin{tabular}{|c|c|c|}
\hline Species/Morphospecies & Funcional Feeding Group & Abundance \\
\hline $\begin{array}{l}\text { Amanahyphes saguassu Salles } \\
\text { and Molineri, } 2006\end{array}$ & Gathering collector & 23 \\
\hline $\begin{array}{l}\text { Aturbina georgei Lugo-Ortiz and } \\
\text { McCafferty, } 1996\end{array}$ & Gathering collector & 3 \\
\hline Brasilocaenis sp. 5 & Scraper & 3 \\
\hline Caenis sp. & Scraper & 5 \\
\hline Callibaetis sp. & Gathering collector & 11 \\
\hline $\begin{array}{l}\text { Callibaetoides caaigua Cruz, } \\
\text { Salles and Hamada, } 2013\end{array}$ & Gathering collector & 7 \\
\hline Campsurus sp. 1 & Filtering collector & 2 \\
\hline Campsurus sp. 4 & Filtering collector & 8 \\
\hline Campsurus sp. 7 & Filtering collector & 21 \\
\hline Campsurus sp. 8 & Filtering collector & 22 \\
\hline Campsurus sp. 9 & Filtering collector & 1 \\
\hline Campylocia spp. & Gathering collector & 799 \\
\hline Cloeodes sp. n. & Scraper & 13 \\
\hline $\begin{array}{l}\text { Cloeodes redactus Waltz and } \\
\text { McCafferty, } 1987\end{array}$ & Scraper & 7 \\
\hline Coryphorus aquilus Peters, 1981 & Gathering collector & 5 \\
\hline Farrodes spp. & Scraper & 140 \\
\hline $\begin{array}{l}\text { Hagenulopsis minuta Spieth, } \\
1943\end{array}$ & Scraper & 17 \\
\hline $\begin{array}{l}\text { Hydrosmilodon aff. gilliasae } \\
\text { Thomas and Péru, } 2004\end{array}$ & Filtering collector & 27 \\
\hline $\begin{array}{l}\text { Microphlebia surinamensis } \\
\text { Savage and Peters, } 1983\end{array}$ & Scraper & 1 \\
\hline Miroculis spp. & Scraper & 1406 \\
\hline $\begin{array}{l}\text { Simothraulopsis cf. sabalo Kluge, } \\
2007\end{array}$ & Scraper & 1 \\
\hline Simothraulopsis sp. n. & Scraper & 7 \\
\hline $\begin{array}{l}\text { Tricorythopsis acara Belmont, } \\
\text { Salles and Hamada, } 2011\end{array}$ & Gathering collector & 7 \\
\hline $\begin{array}{l}\text { Ulmeritoides flavopedes (Spieth, } \\
\text { 1943) }\end{array}$ & Shredder & 90 \\
\hline $\begin{array}{l}\text { Waltzoyphius roberti Thomas and } \\
\text { Peru, } 2002\end{array}$ & Gathering collector & 13 \\
\hline Zelusia sp. 1 & Gathering collector & 62 \\
\hline TOTAL & & 2701 \\
\hline
\end{tabular}


Table 2. Degree of agreement between the PCoA scores for the log-transformed composition and abundance of ephemeropteran nymphs found in the groups of five (5-S), 10 (10-S), 15 (15-S), and 20 (20-S) subsamples per stream. Significance level was set at $\mathrm{p}<0.05$.

\begin{tabular}{lcccc}
\hline Group & & $5-S$ & $10-S$ & $15-S$ \\
\hline \multirow{3}{*}{$10-S$} & $\mathrm{~m}^{2}$ & 0.6071 & - & - \\
& $\mathrm{r}^{2}$ & 0.6269 & - & - \\
\hline \multirow{3}{*}{$15-S$} & $\mathrm{P}$ & $<0.001$ & - & - \\
\hline & $\mathrm{m}^{2}$ & 0.5835 & 0.3595 & - \\
& $\mathrm{r}^{2}$ & 0.6454 & 0.8003 & - \\
\hline \multirow{2}{*}{$20-\mathrm{S}$} & $\mathrm{P}$ & $<0.001$ & $<0.001$ & - \\
& $\mathrm{m}^{2}$ & 0.6419 & 0.3169 & 0.09173 \\
& $\mathrm{r}^{2}$ & 0.5984 & 0.8265 & 0.953 \\
\hline & $\mathrm{P}$ & $<0.001$ & $<0.001$ & $<0.001$ \\
\hline
\end{tabular}

Table 3. Degree of agreement between PCoA scores for the log-transformed composition and abundance of ephemeropteran nymphs according to the taxonomic resolution applied (species/morphospecies, genus, family, and functional categories). Significance level was set at $p<0.05$. FFG $=$ Functional Feeding Groups.

\begin{tabular}{lcccc}
\hline GROUP & & SPECIES & GENUS & FAMILY \\
\hline \multirow{3}{*}{ Genus } & $\mathrm{m}^{2}$ & 0.02 & - & - \\
& $\mathrm{r}^{2}$ & 0.99 & - & - \\
\hline \multirow{4}{*}{ Family } & $\mathrm{p}$ & $>0.001$ & - & - \\
& $\mathrm{m}^{2}$ & 0.446 & 0.357 & - \\
\hline \multirow{4}{*}{ FFG } & $\mathrm{r}^{2}$ & 0.7442 & 0.802 & - \\
& $\mathrm{p}$ & $>0.001$ & $>0.001$ & - \\
\hline & $\mathrm{m}^{2}$ & 0.375 & 0.327 & 0.497 \\
& $\mathrm{r}^{2}$ & 0.791 & 0.82 & 0.709 \\
\hline
\end{tabular}

\section{DISCUSSION}

As expected, the results of the present study indicated that the number of subsamples per stream and the taxonomic resolution could be reduced - up to a point - without having a significant effect on the results of the study. While no significant effect was found on species richness or abundance when the sample was reduced by only five subsamples (15-S), further reductions (10-S and 5-S) had a significant impact. Species composition was consistent between the 20-S and 10-S samples, although there was a significant loss of information on species richness and abundance. Results thus support the conclusion that a study based on 15 subsamples per stream would provide equally reliable ecological data, permitting a reduction in sampling effort and consequent financial costs, in the studied habitat type.
Empirical studies in aquatic ecology are not based on a standardized number of samples or subsamples, and published studies vary considerably in sampling effort, depending on factors such as study objective, geographic location, procedural standardization adopted by a given group of researchers, and so on. Saulino et al. (2014), for example, used three 2-minute subsamples per site using a dipnet to evaluate changes in the aquatic insect community following the construction in Mogi-Guaçu sub-basin, in the state of São Paulo (Brazil) , while Moya et al. (2011) used five samples $\left(0.09 \mathrm{~m}^{2}\right.$ per sample) per stream to characterize antropogenic influences and create a multimetric index, in Bolivian streams, and Kleine et al. (2011) used nine samples of different types to test the effects of banana plantations on macroinvertebrate communities in the Atlantic Forest of Brazil. In contrast, Ligeiro et al. (2012) used 11 samples per stream to test the reliability of macroinvertebrate species richness estimates based on the processing of a standard number of subsamples in Araguari River Basin, Minas Gerais, southeastern Brazil, and Shimano et al. (2013) utilized 20 samples per stream to test the influence of environmental and spatial factors on an ephemeropteran community in Suiá-Missú river sub-basin, Mato Grosso State, Brazil. These examples illustrate the degree of variation that exists, not only in sampling design, but also regarding the number of subsamples collected, depending on the objectives of each study. Melo (2004) concluded that many authors define sample size arbitrarily or without consulting the available literature, while others use a minimum number of samples, e.g., 4-10 sweeps of a Surber net or stones searched. Our findings nevertheless indicate that the collection of 15 subsamples would be the most viable approach, independently of the sampling technique used. This is a more conservative estimate than that of Melo (2004).

A reduction in the number of subsamples collected per stream may not necessarily result in significant savings of field time or costs, depending on logistics, especially where shifting camp between sites is relatively time-consuming. It is nevertheless likely that considerable economy of time and expense will generally be gained in the laboratory.

All different levels of taxonomic resolution tested in the present study (genus, family, and functional group) provided results comparable to those obtained for species/ morphospecies, with correlations above $70 \%$. However, we would recommend the use of a genus-level resolution, given that information loss was negligible (less than 1\%) in comparison to species level analyses, especially as specieslevel identification of aquatic insects demands a high degree of expertise (Martins et al. 2014), especially for immature specimens. This result is valid considering the distribution of Ephemeroptera order in Brazil. According to the species list of Brazilian Ephemeroptera (Salles et al. 2016), at the moment, almost $40 \%$ of the genus is composed for only one species, whereas more than $20 \%$ is composed by two species. In case 
of taxonomic groups that have more congeneric species, we suggest that further studies are conducted.

The high degree of consistency found in the present study between the species and genus level resolutions was similar to that found by Giehl et al. (2014) in insects of the order Heteroptera. These authors concluded that this congruence may be accounted for the small number of species per genus, with more than half the genera being represented by only one or two species, a situation also observed for ephemeropterans in the current study. Heino and Soininen (2007) also recorded a high degree of congruence between macroinvertebrate species and genera, and concluded that community-level patterns in the identification of species, genera or families did not vary.

A large number of studies have attempted to identify the optimum taxonomic level for aquatic macroinvertebrate community analysis (e.g. Heino 2014; Giehl et al. 2014), and for studies of bodies of water, there are disagreements on the use of a family, genus or species taxonomic resolution. Irrespective of the degree of congruence, identification of species will always be a priority in ecological studies, given that congener species do not necessarily have equivalent ecological requirements or the same levels of tolerance of environmental conditions (Merritt et al. 2008). In fact, Heino (2014) found that a species-level resolution is more sensitive for the description of regional differences in the composition of communities because the geographic distribution of a given species is typically much smaller than that of a family or genus.

We believe that the minor loss of information resulting from the shift from a species- to a genus-level may be related to the reduced species diversity of the order Ephemeroptera, which is represented by only 592 recognized species in the Neotropical Region (Salles et al. 2014). While a recent estimate (Cardoso et al. 2015) suggests that the number of as-yet-undescribed species in Brazil is much higher than this, many genera are monospecific. These species include Amanahyphes saguassu Salles \& Molineri, 2006, Callibaetoides caaigua Cruz, Salles \& Hamada, 2013, Coryphorus aquilus Peters, 1981, all of which were sampled in the present study, and in some cases represent monospecific families.

Considering the time spent processing and identifying specimens, we estimate that the identification of ephemeropteran species or morphospecies demands approximately $70 \%$ of total laboratory time (depending on the personal experience of the identifier). In this case, for example, identification of specimens obtained from 10 streams to the genus level would take one week rather than a whole month for the species-level resolution.

In addition to time saving considerations, monitoring studies conducted by environmental consultancies would no longer need to employ a taxonomic specialist, given that most technicians and experienced undergraduates can identify genera relatively reliably. A rough estimate of savings in laboratory expenses can be derived from the values proposed by Gardner et al. (2008) for multi-taxa biodiversity surveys in tropical forests, that is, a $\$ 100$ daily fee for specialists and a $\$ 50$ fee for technicians. Based on these values, the adoption of a genus-level resolution would result in a saving of approximately $\$ 2550$ for the processing and identification of the specimens collected from 10 streams. Given that the study of Gardner et al. (2008) is now almost 10 years old, this value is probably underestimated in comparison with present-day fees.

More precise identification of insect specimens requires more time and financial resources, as well as more specialized data, techniques, and equipment (Jones, 2008). This more detailed approach also demands a considerable investment in the expansion of reference collections and bibliographic material, as well as the more frequent input from taxonomic specialists.

The adoption of a taxonomic resolution above the genus level may help minimize errors of identification, given that the larvae of some genera cannot be differentiated, due to either a lack of data or the similarities among taxa, as in the case of Miroculis, Campylocia and Farrodes. As most of the genera within a family tend to have similar ecosystem functions (see Shimano et al. 2012; Brasil et al. 2014), the adoption of a reduced taxonomic resolution should not have a major impact on the ecological assessment, specially in the case of ecological impact assessments, when time constraints are usually very significant. However, we would recommend a more precise taxonomic resolution for the evaluation of subtle ecological impacts or biogeographic patterns, although this may represent an unnecessary investment of time and resources when the stress under analysis is more severe or obvious (Martins et al. 2014).

\section{CONCLUSIONS}

The results of the current study indicate that it is possible to reduce sampling effort for ephemeroptern nymphs in Amazonian streams from 20 subsamples to 15 without any significant loss of information for species richness, abundance and composition. There was a high degree of correlation between taxonomic composition at species and genus level, suggesting that a genus-level resolution is sufficient for the reliable analysis of ecological response of insects of the order Ephemeroptera to environmental impacts in the studied habitats. A lower-level taxonomic resolution has the advantage of higher cost-effectiveness in both field and laboratory effort, facilitating diagnosis and reducing time needed for identification of specimens,.

\section{ACKNOWLEDGMENTS}

We would like to thank 33 Forest and CIKEL Ltd. for logistic support. We are also grateful to Conselho Nacional 
de Desenvolvimento Científico e Tecnológico (CNPQ) for financial support of the projects entitled "Resilience time of aquatic communities following selective logging in the eastern Amazon basin" (Universal 14/2011, process number 481015/2011-6), "The Influence of the different types of land use on the biodiversity of eastern Amazonia" (CNPq no. 449314/2014-2) and a productivity stipend to LJ (process: 307597/2016-4). Coordenação de Aperfeiçoamento de Pessoal de Nível Superior (CAPES) provided MC with a master's stipend. We would like to thank the editor and the reviewers for their time and valuable remarks.

\section{REFERENCES}

Baptista, D.F.; Buss, D.F.; Dorvillé, L.F.M.; Nessimian, J. 2001. Diversity and habitat preference of aquatic insects along the longitudinal gradient of the Macaé River Basin, Rio de Janeiro, Brazil. Revista Brasileira de Biologia, 61: 249-258.

Baptista, D.F.; Buss, D.F.; Egler, M.; Giovanelli, A.; Silveira, M.P.; Nessimian, J.L. 2007. A multimetric index based on benthic macroinvertebrates for evaluation of Atlantic Forest streams at Rio de Janeiro State, Brazil. Hydrobiologia, 575: 83-94.

Brasil, L.S.; Juen, L.; Batista, J.D.; Pavan, M.G.; Cabette, H.S.R. 2014. Longitudinal distribution of the functional feeding groups of aquatic insects in streams of the Brazilian Cerrado Savanna. Neotropical Entomology, 43: 421-428.

Cardoso, M.N.; Shimano, Y.; Nabout, J.C.; Juen, L. 2015. $\mathrm{Na}$ estimate of the pontetial number of mayfly species (Ephemeroptera, Insecta) still to be described in Brasil. Revista Brasileira de Entomologia, 59: 147-153.

Callisto, M.; Goulart, M.; Medeiros, A.O.; Rosa, C.A. 2005. Diversity assessment of benthic macroinvertebrate; yeasts; and microbiological indicators along a longitudinal gradient in Serra do Cipó; Brazil. Brazilian Journal of Biology, 64: 743-755.

Chakona, A.; Phiri, C.; Magagadza, C.H.D.; Brendonck, L. 2008. The influence of habitat structure and flow permanence on macroinvertebrate assemblages in temporary rivers in northwestern Ziwbabwe. Hydrobiologia, 607: 199-209.

Dodds, W.K. 2002. Freshwater Ecology: concepts and environmental applications. Academic Press, San Diego, 569p.

Domínguez, E.; Molineri, C.; Pescador, M.L.; Hubbard, M.D.; Nieto, C. 2006. Ephemeroptera of South America. Pensoft, SofiaMoscow, 640p.

Gardner, T.A.; Barlow, J.; Araujo, I.S.; Ávila-Pires, T.C.; Bonaldo, A.B.; Costa, J.E.; et al. 2008. The cost-effectiveness of biodiversity surveys in tropical forests. Ecologic Letters, 11: 139-150.

Ghani, W.M.H.W.; Rawi, C.S.M.; Hamid, S.A.; Al-Shami, S.A.; Ahmad, A. H. and Hassan, A.N.N. 2016. Variation in environmental conditions influences diversity and abundance of Ephemeroptera in forest streams of northerm Peninsular Malaysia. Tropical Ecology, 57: 489-501.

Giehl, N.F.; Dias-Silva, K.; Juen, L.; Batista, J.D.; Cabette, H.S.R. 2014. Taxonomic and Numerical Resolutions of Nepomorpha (Insecta: Heteroptera) in Cerrado Streams. PLoS ONE, 9: e103623.
Heino, J. 2014. Taxonomic surrogacy; numerical resolution and responses of stream macroinvertebrate communities to ecological gradients: are the inferences transferable among regions? Ecologic Indicators, 36: 186-194.

Heino, J.; Soininen, J. 2007. Are higher taxa adequate surrogates for species-level assemblage patterns and species richness in stream organisms? Biology Conservation, 137: 78-89.

Hirai, E.H.; Carvalho, J.O.P.; Pinheiro, K.A. 2008. O Estrutura de população de Maçaranduba (Manilkara huberi Standley) em 84 ha de floresta natural na fazenda Rio Capim, Paragominas, PA. Revista de Ciências Agrárias, 49: 65-76.

Jackson, D.A. 1995. Protest - A Procrustean Randomization Test of Community Environment Concordance. Ecoscience, 2: 297-303.

Jones, F.C. 2008. Taxonomic sufficiency: the influence of taxonomic resolution on freshwater bioassessments using benthic macroinvertebrates. Environmental Reviews, 16: 45-69.

Juen, L.; Cunha, E.J.; Carvalho, F.G.; Ferreira, M.C.; Begot, T.O.; Andrade, A.L.; Shimano, Y.; Leão, H.; Pompeu, P.S.; Montag, L.F.A. 2016. Effects of oil palm plantations on the habitat structure and biota of streams in Eastern Amazon. River Research and Applications: doi:10.1002/rra.3050.

Kaufmann, P.R.; Levine, P.; Peck, D.V.; Robison E.G.; Seeliger, C. 1999. Quantifying physical habitat in wadeable streams. EPA/620/R-99/003. U.S. Environmental Protection Agency, Washinton, D.C., 149p.

Khan, S.A. 2006. Is species level identification essential for environmental impact studies? Current Science, 91: 29-34.

Kleine, P.; Trivinho-Strixino, S.; Corbi, J.J. 2011. Relationship between banana plant cultivation and stream macroinvertebrate communities. acta limnologica brasiliensia, 23: 344-352.

Leal, G.L.R. 2000. A realidade do pioneirismo: Paragominas 1959 a 2000. Editora Alves, Belém, 498p.

Legendre, P.; Legendre, L. 1998. Numerical Ecology. 2a Ed. Elsevier Science B.V., Amsterdam, 853p.

Ligeiro, R.; Ferreira, W.; Hughes, R.M.; Callisto, M. 2012. The problem of using fixed-area subsampling methods to estimate macroinvertebrate richness: a case study with Neotropical stream data. Environmental Monitoring and Assessment, 185: 4077-4085.

Martins, R.T.; Oliveira, V.C.; Salcedo, A.K.M. 2014. Uso de insetos aquáticos na avaliação de impactos antrópicos em ecossistemas. In: Hamada, N.; Nessimian, J.L.; Querino, R.B. (Ed.). Insetos aquáticos na Amazônia brasileira: taxonomia; biologia e ecologia. Instituto Nacional de Pesquisas da Amazônia, Manaus, Amazonas, p.117-128.

Melo, A. S. 2004. Diversidade de macroinvertebrados em riachos. In: Cullen, L.Jr.; Rudran R.; Padua C.V. (Eds). Métodos de Estudos em Biologia da Conservação e Manejo da Vida Silvestre. Editora da UFPR, Curitiba, p. 69-90.

Melo, A.S.; Hepp, L.U. 2008. Ferramentas estatísticas para análises de dados provenientes de biomonitoramento. Oecologia Brasiliensis, 12: 463-486.

Merritt, R.W.; Cummins, K.W.; Resh, V.H.; Batzer, D.P. 2007. Sampling aquatic insects: collection devices, statistical considerations and rearing procedures. In: Merritt, R.W.; Cummins, K.W.; Berg, M.B. (Ed.). An introduction to the aquatic 
insects of North America. Kendall/Hunt Publishing Company, Dubuque, Iowa, p.15-38.

Moya, N.; Hughes, R.M.; Domínguez, E.; Gibon, F.M.; Goitia, E.; Oberdorff, T. 2011. Macroinvertebrate-based multimetric predictive models for evaluating the human impact on biotic condition of Bolivian streams. Ecological Indicators, 11: 840-847.

Peck, D.V.; Herlihy, A.T.; Hill, B.H.; Hughes, R.M.; Kaufmann, P.R.; Klemm, D.J.; Lazorchak, J.M.; McCormick, F.H.; Peterson, S.A.; Ringold, P.L.; Magee, T.; Cappaert, M. 2006. Environmental monitoring and assessment program-Surface waters westerns pilot study: Field operations manual for wadeable streams EPA/620/R-06/003. U.S. Environmental Protection Agency, Office of Research and Development, Washington, D.C., 332p.

Phillips, O.L.; Martínez, R.V.; Vargas, P.N.; Monteagudo, A.L.; Zans, M.E.C.; Sánchez, W.G.; Cruz, A.P.; Timaná, M.; Yli-Halla, M.; Rose, S. 2003. Efficient plot-based floristic assessment of tropical forests. Journal of Tropical Ecology, 19: 629-645.

R Development Core Team, 2017. R: A language and environment for statistical computing. R Foundation for Statistical Computing, Vienna, Austria.

Salles, F.F.; Nascimento, J.M.C.; Cruz, P.V.; Boldrini, R.; Belmont, E.L.L. 2014. Ordem Ephemeroptera. In: Hamada, N.; Nessimian, J.L.; Querino, R.B. (Ed.). Insetos aquáticos na Amazônia brasileira: taxonomia; biologia e ecologia. Instituto Nacional de Pesquisas da Amazônia, Manaus, Amazonas, p.193-216.

Salles, F.F.; Boldrini, R.; Nascimento, J.M.C.; Angeli, K.B.; Massariol, F.C.; Raimundi E. 2016. Ephemeroptera do Brasil (http://ephemeroptera.com.br/lista/). Acesso em 06/11/2017.
Saulino, H.H.L.; Corbi, J.J.; Trivinho-Strixino, S. 2014. Aquatic insect community structure under the influence of small dams in a stream of the Mogi-Guaçu river basin; state of São Paulo. Brazilian Journal of Biology, 74: 79-88.

Shimano, Y.; Juen, L.; Salles, F.F.; Nogueira, D.S.; Cabette, H.S.R. 2013. Environmental and spatial processes determining Ephemeroptera (Insecta) structures in tropical streams. Annales de Limnologie - International Journal of Limnology, 49: 31-41.

Shimano, Y.; Salles, F.F.; Faria, L.R.R.; Cabette, H.S.R.; Nogueira, D.S. 2012. Distribuição espacial das guildas tróficas e estruturaçấo da comunidade de Ephemeroptera (Insecta) em córregos do Cerrado de Mato Grosso; Brasil. Iheringia, Série Zoologia, 102: 187-196.

Tonello, G.; Loureiro, R.C.; Krause, P.; Silva, C.; Ongaratto, R.M.; Sepp, S; Restello, R.M.; Hepp, L.U. 2014. Colonização de invertebrados durante a decomposiçáo de diferentes detritos vegetais em um riacho subtropical. Revista Brasileira de Biociências, 12: 98-105.

Watrin, O.S.; Rocha, A.M.A. 1992. Levantamento de vegetação natural e uso da terra no Município de Paragominas (PA) utilizando imagens de TM/Landsat. EMBRAPA-CPATU, boletim de pesquisa, Belém, 124, 40p.

Zar, J.H. 2010. Biostatistical analysis. 5 ed. Prentice-Hall, New Jersey, 944p.

RECEIVED: 25/02/2017

ACCEPTED: 06/11/2017

ASSOCIATE EDITOR: Ana Lúcia Tourinho 